Vol. 8, n² | 2004

Varia

\title{
Contexts, Representation and the Colonized Convict: Maulana Thanesari in the Andaman Islands
}

Satadru Sen

\section{(2) OpenEdition Journals}

Electronic version

URL: https://journals.openedition.org/chs/467

DOI: $10.4000 /$ chs. 467

ISSN: 1663-4837

\section{Publisher}

Librairie Droz

\section{Printed version}

Date of publication: 1 November 2004

Number of pages: 117-139

ISBN: 2-600-00803-5

ISSN: $1422-0857$

\section{Electronic reference}

Satadru Sen, "Contexts, Representation and the Colonized Convict: Maulana Thanesari in the Andaman Islands", Crime, Histoire \& Sociétés / Crime, History \& Societies [Online], Vol. 8, n² | 2004, Online since 26 February 2009, connection on 22 March 2022. URL: http://journals.openedition.org/ chs/467; DOI: https://doi.org/10.4000/chs.467

This text was automatically generated on 22 March 2022.

(C) Droz 


\title{
Contexts, Representation and the Colonized Convict: Maulana Thanesari in the Andaman Islands
}

\author{
Satadru Sen
}

1 Between the Indian Rebellion of 1857 and the Japanese victories of 1942, the British Empire and its prisoners collaborated in the development of an elaborate society of convicts in the Andaman Islands, eight hundred miles off the east coast of India. To create a semblance of order in this settlement of twelve thousand rebels, murderers, thieves, infanticidal mothers, members of so-called «criminal tribes ${ }^{2}$ ", and thousands of indigenous Andamanese, colonial administrators devised a complex system of punishment and reward, control and patronage, utilizing systems of labor, segregation, surveillance, medical supervision, and family-based rehabilitation ${ }^{3}$ As these systems emerged, the prisoners themselves became partially and inconsistently self-policing, trying to access the advantages of cooperation with the colonial regime, even as they resisted or remained indifferent towards British authority.

2 Scholarship on the first fifty years of the Andaman Islands penal colony is marked by an acute paucity of first-hand narratives by the convicts themselves. Such narratives are relatively abundant in studies of Australia, and to a lesser extent French Guiana ${ }^{4}$. Researchers such as Yang and Anderson, who study the overwhelmingly non-literate British-Indian convict diaspora, must necessary glean most of their information from government documents, and from the private writings of British administrators and visitors to the penal colony ${ }^{5}$. A rare Indian convict autobiography from the Andamans in the nineteenth century is an Urdu narrative by the Maulana Muhammad Jafar Thanesari, a Wahhabi arrested in 1863 for conspiring to smuggle funds to anti-British mujahideen in Afghanistan. He was initially sentenced to death, but his punishment was commuted to life in penal transportation, which meant exile in the Andaman Islands ${ }^{6}$. Beginning in 1866, he spent nearly eighteen years in the penal colony, and then returned to Punjab with a new wife, new children, and considerable wealth and social status. If punishment is defined as the correction of a flawed political 
relationship, the colonial regime's treatment of Thanesari was quite successful, because it resulted in the conversion of a trouble-maker into a moderately satisfied and lawabiding subject of the crown. It did not, however, eradicate all inclinations and opportunities for dissent - rather, it produced, reproduced, and gave new form to dissident gestures ${ }^{7}$.

We must be careful not to ascribe to Thanesari the voice of the 'typical' or 'subaltern' convict. The very fact that he wrote his memoirs marks him as a member of the convict elite $^{8}$. His status in the penal colony, and his status in mainland society upon return, both derived ultimately from his literacy in multiple languages: Urdu, Farsi, Hindi, and eventually English. The voice that emerges from the manuscript is that of the incarcerated intermediary: by turns colonized and colonizer, a subject who recognizes the authority of his British superiors but who disregards that authority whenever he can get away with it, a man who is both resentful and grateful, a convict who feels his humiliation but who is nevertheless conscious of his high status in the society of the humiliated.

It is also an unreliable voice that must be heard with caution. This article is, among other things, an experiment in reading a document of doubtful veracity, in which what is true and productive is unreliability itself. Thanesari wrote his memoirs after his return to the mainland, and the narrative is very much an attempt on the part of the author to represent himself in a particular light, or multiple lights, before an audience of his peers in northern India: fellow-Wahhabis, the Muslim elite in provincial cities, and more broadly, an Urdu-literate post-1857 readership that shared with him the experience of being simultaneously traumatized and rewarded by the colonial encounter. This audience had evolved significantly in the two decades following Thanesari's departure for the penal colony. In the 1880s, the political milieu of Islam in India was informed not only by numerous 'little traditions' of regionally structured Muslim communities, but also by a cosmopolitan intellectual tradition which lent itself to pan-Islamic identities and activism, and by partially state-sponsored formulations of an Indian-Muslim community that might be deployed in opposition to Hindus or, perversely, in opposition to the colonial regime ${ }^{9}$. In this context, Thanesari found it necessary to represent his participation in the improvised (and aberrant) bureaucratic, intellectual, communal and familial world of a penal settlement as an apologia, and as an experience of martyrdom. While this agenda leads him to deviate constantly from what might be considered the 'archival truth' of documented episodes and policies, it is nevertheless an exercise in colonial world-construction, in which the incarcerated/ colonized subject attempts to reorder his surroundings by transforming the ambiguously rewarding experience of the modern into unambiguous affirmations of fundamental truths and identities. Fundamentalism, Harjot Oberoi has pointed out, is nothing if not a modern enterpris $\mathrm{e}^{10}$. Thanesari's narrative is thus at once a kind of adventure-travel literature calculated to attract readers curious about life in a notorious penal colony, and an attempt to put forward his personal tragedies and ultimate triumph over the adversities of a banishment that is political, spiritual and social.

5 The nature of the triumph and the adversity are both rooted in the author's selfconscious religious and political identity as a Wahhabi ${ }^{11}$. Exile not only gave Thanesari the material with which to reinforce his Wahhabi credentials, it also produced the need for reinforcement by immersing him in experiences, knowledges and perspectives that 
destabilized his Wahhabi identity. Thanesari uses his memoirs to represent his punishment as a series of religio-political trials, which test his faith and present him with opportunities to prevail over his personal weaknesses and communal adversaries. Ayesha Jalal has noted Thanesari's self-positioning within the Wahhabi ideology of jihad, i.e., struggle that is personal/spiritual as well as communal/political ${ }^{12}$. As Jalal has also pointed out, the construction of such struggles must be understood in their temporal context ${ }^{13}$. Thanesari's struggles must be examined, therefore, in the setting of the colonial encounter. There can be little doubt that the Maulana translated his imprisonment in ways that might promote his status as a heroic spiritual and political figure in concentric circles of the colonized faithful: Wahhabis and Muslims, convicts and the 'free.'

6 Given its investment in the response of the reader, the published narrative lacks the «honesty» of a diary. As the Rudolphs have noted in their study of the memoirs of another colonial subject, even diaries are written with potential readers in $\operatorname{mind}^{14}$. There are two overlapping levels of unreliability in Thanesari's memoirs, which correspond to the 'lived' context of the penal colony and the 'represented' context of the mainland. Not only does he have many opportunities to misrepresent (or reinvent) himself in the society of convicts, he has the chance to misrepresent the original misrepresentation upon returning to the mainland as an author. As far as possible, I have attempted to check Thanesari's story against other sources of information about convict society in the Andamans, so that we might utilize the emphases, distortions, and silences within his narrative.

7 What I intend to do is search Thanesari's narrative of penal transportation for insights into the nature of the penal colony, the nature of the penal experience, and the nature of a convict self-representation. I shall focus first on the issue of convict labor, and the benefits that this conferred upon the 'laborer.' The work that Thanesari did in the penal colony demonstrates that punishment in the Andamans operated on a market principle of sorts. Because the British needed loyal intermediaries at every level of the prison administration, they were obliged to bargain with convicts who might serve in such positions, and to reduce the punitive content of punishment. For convicts who possessed certain qualifications, such as literacy, the penal experience could generate unparalleled opportunities for professional and social advancement, and dramatically altered relationships with the punishing colonial state. At the same time, the nature and circumstances of the work could severely destabilize the identity of the worker, compelling him to make compensatory gestures that might reassure his audience about his social and political location.

8 I shall then examine Thanesari's perceptions of the politics of religion and race in the Andamans. The nineteenth century, Francis Robinson has observed, was marked by sharply increased levels of status-anxiety, ideological ferment, and self-assertion among Muslims who belonged to the intertwined landowning, administrative, and clerical classes of late-Mughal India ${ }^{15}$. After 1858, especially, these Muslims sought to reposition themselves in a colonial state which was not interested in their religiopolitical priorities, and which forced them to compete professionally and politically against better-equipped outsiders and unbelievers. The tension manifested itself in diverse Islamic-revivalist and modernizing movements on the mainland (such as the Deoband madrasa, Aligarh College, the Dars-i-Nizamiyya, and the Wahhabi insurgency that Thanesari was connected with $\left.{ }^{16}\right)$, and it was very much present in the contested 
society of the penal colony. We find a high degree of communal self-consciousness in segments of the convict population, and intense competition between Hindu and Muslim convicts for access to the colonial state. We find, also, that under certain circumstances, this animosity was submerged under an Indian convict identity that was defined in opposition to the colonizer, and defined also by the experience of punishment. This political and penal context determined the Maulana's ability to choose between the identities of a Wahhabi, a Muslim, and a colonized and punished Indian.

9 Finally, I examine Thanesari's acquisition of a family in the islands. Women and families in the Andamans were central to the British effort to control and rehabilitate male convicts by domesticating disorderly men $^{17}$. Thanesari's narrative allows us to see how male convicts themselves may have viewed these rehabilitative mechanisms. It indicates that the right to marry and have children in the penal colony was not simply an incentive to good behavior and a disincentive to homosexuality, but also a marker of wealth and success, an opportunity for religious proselytization, and a source of relief from the loneliness of life in the Andamans. It casts light, also, on the problems that developed when convicts who already had families on the mainland married again in the islands, and tried to choose between two places, families, and societies.

\section{Privileged/Worker}

In the nineteenth-century discourse of crime, criminality was very substantially defined as the reluctance to work ${ }^{18}$. Much of punishment in Victorian Britain and its colonies was geared towards putting the idle to work, within and without the prison ${ }^{19}$. The labor regime in the Andaman Islands was divided very broadly into two phases: a painful phase of closely supervised forced labor, which lasted up to ten years, followed by a period of rehabilitative labor, when the convict worked under conditions of greater autonomy, and was given a tangible share in the fruits of his or her exertions ${ }^{20}$. Whereas the first phase underlined the political supremacy of the colonial state over the individual criminal, the second phase was a process by which offenders could be rewarded for their obedience, and integrated into the legitimate structures and hierarchies of the penal colony.

11 There is, however, no doubt that at least some convicts were allowed to bypass the initial stage of punitive labor. This was due in no small measure to the colonial state's perpetual search for reliable prison employees. Arnold has argued that colonial prison regimes encountered serious disciplinary problems with their employees, including convict workers ${ }^{21}$. There can be little doubt, however, that British prison administrators in India in the second half of the nineteenth century preferred convict workers over free employees when it came to appointing guards, overseers, and clerks $^{22}$. Free workers were almost uniformly seen as corrupt, sullen, lazy, and disorderly, and as agents of disorder among the convict population ${ }^{23}$. Convict employees, on the other hand, tended to be the 'better sort' of prisoners, who had acquired their positions of responsibility by demonstrating their obedience. Also, the prison regime could - in theory - punish them if they misbehaved. In the Andamans, free employees were almost completely eschewed by the British authorities ${ }^{24}$. This was substantially due to the great ideological significance of labor in a penal colony where prisoners stayed for long periods, and where it was possible to train convicts to 
perform hierarchically organized tasks. ${ }^{25}$ Colonial administrators were fond of reiterating that the Andaman Islands were not simply a prison, but a colony in the full sense of the term: men and women were brought here not so much to be punished, as to be redeemed and resocialized through the discipline of labor ${ }^{26}$.

There can be little doubt that the regime's reliance on convict labor gave prisoners the power to bargain for status, comfort, and, ironically, freedom from labor ${ }^{27}$. The settlement's need for qualified clerical staff created an instant elite among literate convicts. The privileged status of clerical workers was, in fact, part of the folk knowledge of the penal colony. When Thanesari arrived in the Andamans, he was apparently told by another prisoner: «The clerks are the rulers and the masters here. They can do anything they want ${ }^{28} »$. This rumor of privilege was then visually confirmed: even before he had disembarked from the convict ship Jamuna, Thanesari saw a long line of men, dressed immaculately in white, waiting at the quay. These, he writes, were «Maulvis and clerks ${ }^{29}$ ». Upon landing, Thanesari seems to have escaped the long lines, the humiliating interrogations, the classificatory procedures, the close confinement, the bar fetters (a prime cause of gangrene and death), and the chain gangs that awaited most newly arrived convicts in the Andamans. He escaped, also, the convict uniforms and the meager rations. It is possible that he exaggerates his good fortune to keep his post-carceral reputation as 'respectable' as possible. Given Thanesari's investment in the Wahhabi ideology of martyrdom, however, this seems unlikely. Thanesari does not shrink from providing details of the torture and forced marches he endured before embarking for Port Blair ${ }^{30}$. It is credible, therefore, that he was welcomed at the dock by prisoners who had apparently known he was coming. He was taken to the home of a clerk in the marine department. There, his shackles were removed. He was given good clothes to wear, and introduced to various «respected persons» (all convicts).

Thanesari was appointed Deputy Chief Clerk at the court of the superintendent of the penal colony. He moved into a comfortable house, and not the barracks in which convicts usually lived in the initial phase of their stay in the Andamans. The Maulana was given full freedom within the confines of the penal colony, and, to make life even easier, he was assigned a servant, whose wages were paid by the settlement authorities. For a twenty-seven year-old who had been convicted of sedition and almost hanged, this was a remarkable social and professional recovery. Such a turn-around of fortune would have been impossible on the Indian mainland. In the Andamans, however, frontier conditions and the agenda of rehabilitation combined to create precisely such opportunities.

It is worth asking how the Port Blair authorities came to the conclusion that Thanesari was worthy of privileged treatment. Although the British made energetic efforts to generate and transmit information about convicts who were transported to the Andamans, the systems of record-keeping and surveillance were less than fail-safe. It was not unknown for prisoners to step off the transport ship into a void of official knowledge ${ }^{31}$. In Thanesari's case, it seems that the British gathered their information about the prisoner not from official sources such as Thanesari's «history sheet,» but from convicts who were already present in the settlement. These included men who had been a part of Thanesari's social circle in Punjab, and who had slipped into clerical jobs in the Andamans. They had known in advance that Thanesari was coming, demonstrating, again, that far from being utterly isolated from mainland society, the 
Andamans were in fact a part of the mundane universe of colonial India, connected to the mainland through letters, rumors, and the constant back and forth of convicts. Thanesari thus had a familiar social niche waiting for him when he arrived in the islands. Within this niche, he had a reputation that was substantially independent of the punishing colonial state. Allowing for his interest in exaggerating his own importance, it is likely that his fellow convicts recognized him as a member of the respectable classes, with a certain status as a learned man. The colonial state borrowed this reputation from the society of convicts, and used it to determine Thanesari's status in the official hierarchy of the penal colony.

In a circular process, official privilege boosted Thanesari's standing the society of convicts, and even in the society of the free. He understood this process and did his best to help it along. Not long after his arrival in the islands, he began to write letters to old acquaintances in Punjab, filled with glowing descriptions of his comfortable life and his «independent government job.» In fact, Thanesari admits, he «exaggerated» his comforts, in order to «make those people jealous who had given false testimony against innocent Muslims and were living a shameful life ${ }^{32}$ \%. This is a curious confession, simultaneously undermining and reinforcing the credibility of the confessor. It is, however, entirely consistent with Thanesari's self-representation as a flawed saint and politician: a man whose credentials as a Wahhabi are communicated through his frequent criticism of his own weaknesses, which are then legitimized by his unimpeachable political intentions.

The effort at projecting a good life in the penal colony was more successful than Thanesari had intended. His letters came to the attention of the Government of India and the Punjab administration, and became the subject of consternation. John Lawrence, the governor of Punjab, demanded that Thanesari be subjected to hard labor for the duration of his sentence, and H. Man - the superintendent of the Andamans settlement - was asked to explain why a convict in a penal colony was living an apparently painless life. In spite of this embarrassment, Man's administration did not retaliate against Thanesari. He did not find himself working in a chain gang. His house, job, and servant were not touched.

17 Thanesari attributed this reprieve to the bureaucratic difficulty of retracting official privileges. He added that the Port Blair authorities were unfamiliar with the Rebellion of 1857, and thus not prejudiced against Wahhabis ${ }^{33}$. The explanation is quite implausible. The Andamans settlement was established as part of the larger British reaction to the crisis of 1857 , and the memory of the rebellion had a long life in the penal colony ${ }^{34}$. Moreover, even as administration in the Andamans became increasingly bureaucratized, superintendents had a great deal of discretion in dealing with convicts, especially in situations that could be interpreted as problems of order or discipline. The only circumstances in which superintendents were required to seek the authorization of the Government of India involved the death penalty and the deportation of convicts from the settlement ${ }^{35}$. Man's regime was thus unlikely to be hampered by an exaggerated sense of bureaucratic propriety, and Thanesari's odd observation is almost certainly related to his desire to imagine the penal colony as a geography where the political baggage of the mainland could sometimes be made to disappear.

What is most likely is that the regime treated Thanesari leniently because it needed his services. To ensure his cooperation, it was willing to forgive his local trespasses, even if it meant crossing the colonial government on the mainland. The tension between 
administrators in Calcutta who wanted predictable punishment, and administrators in Port Blair who wanted to maximize their own flexibility, was a persistent feature in the history of the penal settlement ${ }^{36}$. The two conflicting approaches to prison administration represent a transition in the ideology of punishment that was more or less complete in England by the nineteenth century, but that was still unfinished in colonial India. As Douglas Hay has noted about eighteenth-century English criminal justice, provisions for discretion in the enforcement of the law allowed judges, police officers and administrators to be unpredictably merciful ${ }^{37}$. The Benthamite contention that justice must be consistent and precise - and as such, neither vicious nor merciful was, in the early 1800 's, relatively alien to English thought. Mercy as an instrument of authority was imprecise, irrational and pre-modern, but it was well-suited to a political environment that privileged personalized ties of deference, gratitude, loyalty and obedience. Thus, even as the British on the mainland sought to standardize colonial punitive practices, the British in the Andamans operated on the understanding that their control over the convict population depended upon the power to intervene personally and unpredictably in local society. This meant not only the power to be unpredictably punitive, but also the power to be unexpectedly lenient, as Man was with Thanesari.

The Maulana would benefit repeatedly from the Port Blair regime's inclination to protect him. When he was forced to appear in court on charges of theft, Man swallowed his anger and exonerated him. Thanesari is vague about the accuracy of the allegations, but he admits that he violated regulations when, in 1870, he tried illegally to purchase «some essential items for my marriage» from the mainland. He was found out, but once again, shielded from punishment by Man and his deputy, M. Protheroe ${ }^{38}$ The latter, especially, was an invaluable source of support to Thanesari. In the final years of the Maulana's stay in the penal colony, he was Chief Clerk in Protheroe's office in Aberdeen. Protheroe was not simply Thanesari's superior; he was also his student. Educated convicts like Thanesari were sometimes employed as language instructors to British administrators in the Andamans, and it is reasonable to speculate that the dynamics of the teacher-student relationship subverted and altered the convict-jailor relationship, and modified the relationship between the colonized Indian and the colonizing European.

Thanesari's privileged status also shaped the circumstances under which he returned to the mainland. (For most convicts in the Andamans, «life in penal transportation» actually meant a period of twenty years. Since Thanesari had been arrested in 1863, his sentence expired in 1883.) He showed a strategic reluctance to return to Punjab, pointing out to the authorities in Port Blair and Lahore that it made no sense for him to give up his «excellent house and a good job which gives me 100 rupees,» for a life of uncertainty, unemployment, and harassment by the local police. With the support of Protheroe, who wrote him glowing letters of recommendation, he was actually able to negotiate the terms of his release and repatriation: the government of Punjab promised him a job commensurate with his status in the penal colony ${ }^{39}$.

Thanesari's return to the mainland reflects just how penal transportation could affect the social status of privileged convict employees. After nearly two decades overseas, he was able to claim that he had returned not in disgrace or in obscurity, but in triumph. Crowds of well-wishers greeted him in Delhi, Thanesar and Ambala. Once again, information had travelled between the penal colony and the 'free' colony 
independently of the colonizer; Thanesari's letters and reputation had preceded him to the mainland. He was also able to take with him the knowledge about himself that he had negotiated with the punishing state. In Ambala, he was given a job as a languagetrainer for colonial civil servants: a position that indicates a successful reintegration into the political universe of British India. At the same time, ambiguities crept into this heroic homecoming. Thanesari's salary in Port Blair had been twice as high as his wages on the mainland. Also, consistent with a chronic complication in colonial projects for the rehabilitation of released prisoners, police surveillance over his activities appears to have continued in Ambala, even as he worked closely with British officials ${ }^{40}$. In a sense, Thanesari had been more privileged as a prisoner in the penal colony than he was after his release.

It is clear that immunity from punishment was not the only perquisite of Maulana Thanesari's life as a clerk in the Andamans. The job allowed him to develop independent sources of wealth and prestige, and to cultivate skills that further boosted his social and professional status. He was entrusted with large amounts of government funds, and there is no doubt that he engaged in illegal trade with his contacts on the mainland by exploiting his ability to manipulate official records. Beginning in 1872, he learned English, which expanded the scope of his clerical responsibilities, and enhanced his status with administrators as well as with convicts who had need for his services. He taught Farsi, Hindi and Urdu to other upwardly-mobile convicts, and drafted appeals and applications for prisoners who wanted to approach the local administration ${ }^{41}$. Convicts in a complex penal settlement such the Andamans frequently needed access to the local government, not only to defend themselves against the threat of punishment, but also to safeguard property acquired in the islands. This work earned Thanesari more than a hundred additional rupees each month, and it allowed him to represent himself as an effective defender of Muslim convicts in their disputes with non-Muslims. He notes that he was instrumental in saving several men from the executioner's noose, and that such men were eternally grateful ${ }^{42}$. This gratitude became part of a political standing that was autonomous of the colonial administration, even as it was enabled by the Maulana's position within the administration.

\section{Indian/Muslim}

It is evident from Thanesari's writing that employment in the prison administration, and the maintenance of the political status of communities defined in terms of religion and race, were closely connected in the Andamans. This connection was by no means universal in nineteenth-century penal colonies; Anderson's study of Mauritius in the first half of the nineteenth century does not reveal any persistent Hindu-Muslim rivalry ${ }^{43}$. In the Andamans, race and religion were both officially recognized as principles of social organization. European and Eurasian convicts lived separately from other prisoners, and were subject to different codes of discipline and punishment ${ }^{44}$. Muslims and Hindus were classified, transported, and fed separately, as were «upcountry men» and prisoners from the south and the east of India. There were regulations in place that recognized, restructured, and regulated the boundaries of caste $^{45}$. In the twentieth century, the British routinely used subaltern Muslim convicts as overseers with authority over elite Hindu political prisoners. It is evident from the 
outraged rants of V.D. Savarkar that this double deployment of religion and class was resented by at least some of the Hindus, and relished by the overseers ${ }^{46}$.

As a representative of a mid-nineteenth-century social and political milieu that was marginal to the English-literate core of colonial India, Thanesari provides a perspective on intercommunal relations in the penal colony that is different from that of either the British administrator, or the twentieth-century Hindu nationalist. Nevertheless, Thanesari's writing indicates that some of the tensions of Savarkar's time had their parallels in the Andamans in the 1860s and 1870s. His recollections highlight, especially, an intense competition between self-aware ethnic groups, and a willingness on the part of convicts to use the state as an instrument of competition. They also indicate that this competition could provide a forum for articulate prisoners in search of local political careers and subsequent reputations as heroic leaders of contextually defined communities.

Antagonism between Muslims and Hindus is the most prominent example of this competition. Thanesari recognized the court - or rather, the court bureaucracy - as an offensive and defensive weapon in this antagonism, as well as a vital battleground that both communities sought to capture and control. His own use of English-language clerical skills to defend Muslims against non-Muslims is only one example of this contest. When Thanesari's illegal trading activities were discovered, it was because Hindu clerks had intercepted his correspondence, and taken the evidence to the superintendent. Thanesari's defense included references to these religious tensions in convict society, and when Protheroe and Man decided to overlook his offense, they apparently did so with a warning: «Hindus are your enemies. Be careful ${ }^{47}$ ».

The specifics of the tension that Thanesari referred to in his own defense concerned cattle-slaughter in the penal colony. John McLane has dated the modern cowprotection movement on the Indian mainland to Kuka revivalism in Punjab in 1870, and located it within a larger context of Islamic revivalism as well as Hindu-nationalist mobilization $^{48}$. It appears that convicts in the Andamans anticipated the Kukas by a year. The specifics of bovine politics in the islands reinforce Sandria Freitag's contention that cattle riots in British India functioned to create new public spaces, agendas and organizations in partial autonomy from the state ${ }^{49}$, but they also show how political affiliations could be asserted, negotiated, qualified and represented within such semi-autonomous forums. In April of 1869, Muslim convicts in the settlement decided to sacrifice a bull during the Id festival. Hindu prisoners objected vehemently, but the bull was killed anyway. Thanesari writes:

The Hindus, as is their nature, became very agitated. When the sacrificial blood flowed in front of the Hindus, there were riots and much uproar. Had the police overseer not arrived in time, a great deal of bloodshed would have occurred and many would have lost their lives ${ }^{50}$.

After police intervention had prevented a wider riot, the cow-protection battle moved into the local courts, and into the domain of convict clerks. As a Wahhabi, a court clerk, and an autobiographical author, Thanesari occupies a strategic location within and without the story. Not surprisingly, it appears that he played a central role in the controversy; he writes that the Hindus (again, «as is their nature») went to court in order «to get me severely punished.» When the court - presided over by Protheroe disappointed the defenders of the local cattle, the enraged Hindus apparently retaliated against Thanesari by framing him on charges of embezzlement ${ }^{51}$. The assumption by 
Thanesari of his own centrality in the matter is not simply a failure of modesty. Thanesari was in fact central, not only because he had asserted (and subsequently advertised) his leadership in the society of Muslim convicts by leading the effort to sacrifice the bull, but also because as a court clerk, he had his hand on the legitimizing apparatus of the colonial state. The convicts recognized that the court in Port Blair was not simply the voice of British administrators like Protheroe, but the voice, also, of the convict intermediaries who influenced Protheroe's opinion.

Thanesari alleges that when he was charged with embezzlement, a Hindu clerk named Monga Lal tampered with the official records to furnish the accusers with supporting evidence. Other Hindu bureaucrats apparently connived to bribe witnesses, and confiscated Thanesari's account books. Thanesari, however, was able to conspire with a Muslim clerk to recover his account books, and to «correct» the «tampered» records. The embezzlement charges were dismissed by Protheroe, who also ordered that Monga Lal be imprisoned for six months (presumably on Viper Island, where local offenders were sent), and that another Hindu clerk be flogged. Before proceeding to Viper Island, however, Monga Lal sprang another unpleasant surprise on Thanesari: he told Protheroe that the Maulana had diverted government timber to build furniture for his own house. He even offered to escort Protheroe to Thanesari's house, so that Protheroe might see for himself. Thanesari concedes that this accusation, at least, was true ${ }^{52}$. This time, he was saved by Protheroe's reluctance to send his favorite clerk to Viper. Protheroe told Monga Lal that the timber was a gift, warned him to stop spying on Thanesari, and sent him on his way ${ }^{53}$.

Thanesari arrived in the Andamans with a highly developed sense of his Wahhabi identity, and an acute perception that Hindus were likely to be a hostile group. At least partially, he blamed his criminal conviction on Hindus ${ }^{54}$. In the penal colony, he seems to have slipped into social milieu that was largely, if not exclusively, Muslim. Hindus, however, were not the only 'enemy' that he recognized in the Andamans; nor did he consistently view Hindus as a menace. He reserved his longest and most articulate diatribes for Europeans, Eurasians, Indian Christians, and the English language itself. Here, also, the context for the hostility was the Port Blair bureaucracy.

Thanesari was conscious, and intensely resentful, of the privileged status of European, Eurasian, and Christian convicts in the Andamans. He pointed out that while Indians from the highest ranks of mainland society were subjected to humiliating and painful labor in the penal colony («because of their black skin and Indian birth»), other prisoners («white-skinned Europeans and many black-skinned Anglo-Indians, who had embraced Christianity and used to wear European dress») were assigned lighter work, residential bungalows, better food, and servants. A special target of Thanesari's ire was an Indian Christian prisoner named Thastier, who had been arrested in Awadh and given a job in the court of the Deputy Commissioner of the Andamans, along with a furnished house and a paid servant ${ }^{55}$.

31 Thastier thus had essentially the same privileges in the penal colony that Thanesari himself took for granted. This provides at least a partial explanation of why Thanesari took such exception to him. Thanesari's privileged life in the Andamans was a social resource to him, in the sense that it reinforced his credentials as a leading member of convict society. Nevertheless, it is likely that such privilege was simultaneously a source of marginalization and resentment: it conveyed an insider status in the penal regime that cut him off from less privileged convicts. Thanesari's attacks on Thastier 
and others like him can be seen as an attempt to counteract this alienation. When Thanesari wrote that «the discrimination [by the settlement authorities] in favor of European dress... made all of us sad and angry,» [italics mine] he was trying to insert himself into a very specific convict «us,» based on black skin, non-Christian religion, non-European dress, and distance from the white/Christian colonial Other.

This vision is evident in Thanesari's admiration for Sher Ali, the convict who assassinated the Viceroy, Lord Mayo, in $1872^{56}$. It is manifest also in the inclusive and sympathetic language which he uses, periodically, to describe Hindu convicts. He compares Thastier's privileged life not with the hardships of the «innocent Muslims» whom he mentions elsewhere, but with the humiliation of the Hindu raja of Jagannath Puri, who came to the Andamans as a political prisoner. The raja, Thanesari noted with anger, was compelled to do hard labor alongside low-caste convicts, and flogged when he was physically unable to work ${ }^{57}$. The raja died not long after his arrival in the penal colony. This treatment of the raja anticipates the British handling of middle-class political prisoners in the islands in the twentieth century; in each case, the reversal of status was a major part of the punishment.

Thanesari could be inclusive towards Hindus and Sikhs in contexts other than that of life in the Andamans: reflecting on the recent history of the subcontinent, he expressed admiration for «the dignity and honor» with which the Sikhs had ruled in Punjab, and the Marathas in the Deccan ${ }^{58}$. Because the Sikh and Maratha regimes were among the last major pre-colonial powers in South Asia ${ }^{59}$, such celebratory references are rich in coded meaning, especially when they come from a Muslim writer who is also prone to waxing nostalgic about Mughal power. Thanesari emerges as a proto-nationalist of sorts: a man who shares the nostalgic and defensive world-view of elite Muslims in mid-nineteenth-century India, but who is also groping for the language and symbols that might fashion a broader Indian identity defined in opposition to white/Christian identity and privilege.

The allegation of nationalist inclinations is necessarily tenuous in the case of a man who locates himself within a transnational religious ideology. Nevertheless, the separation between the transnational anti-colonial politician and his nationalist counterpart is rarely 'clean' in India after the Mutiny ${ }^{60}$. Moreover, I would argue that the nature of the colonial penal settlement, with its reliance on modern bureaucratic categories of nationhood, race, geography and power concentrated within the confines of a community that was both lived and imagined ${ }^{61}$, made it almost inevitable that the politics of resistance would be articulated occasionally in national terms by those who had already learned to imagine large and historically charged political communities. A penal colony which British jailors could imagine as a model colony ${ }^{62}$ could also be imagined by convicts as a model India, in which nationhood manifested itself as extraordinary socio-political reconfigurations. Expressing his wonderment at the convergence of identities bound not only by a pre-existing notion of 'India' but also by subjection to a common punishing agent, Thanesari wrote:

What an interesting place this is! I think there is no other place in the world where people from so many different ethnic backgrounds live together. Just try to imagine that a Bengali man is married to a Madrasi woman, or a Bhutia man is married to a Punjabi woman. The spouses don't understand each other's language, and when they fight, each uses his or her language which is incomprehensible to the other. When there is a wedding, and women from different regions, each wearing the clothes of her homeland, gather to sing songs in their own languages and dance in 
their own way, it is a wonderful scene to watch. Restrictions of caste and region, from which all of India suffers, are totally absent here. You will find a Pasi woman in a Brahmin's house, and a Brahmin woman in a Jat's house ${ }^{63}$. harmful») and specific types of English literature («that are against the teachings of the Prophets»). Whereas knowledge of the language is an asset in the colonial world, the literature is a virtual minefield.

Such knowledge will certainly make a person irreligious and atheistic if he is not well-acquainted with Islam. It will create doubts in his mind which will last a lifetime. And although he may claim to be a Muslim, he will not be a true believer ${ }^{67}$. 
40 and represent his exploration of new cultural territory. Thanesari went on to describe his own brush with self-destruction, noting that his faith had weakened, that his ritual observations had become irregular, and that he had all but forgotten the Hadees.

41

Eventually, the Maulana writes, he underwent a physical test of faith: he became seriously ill. When, after much repentance, he finally recovered his health, he resumed his neglected religious rituals. He did not, however, abandon the English language and his dangerous books. Unwilling and unable to turn away from the guilty pleasures of colonialism, he learned to make the gestures of compromise that made it possible to live with seemingly irreconcilable cultural and moral identities. This compromise was not simply the resolution of a private existential dilemma. It was also the answer to a vitally important political question, which had to do with his ability to retain his status in the society of the punished/colonized even as he penetrated more deeply into the society of the punisher/colonizer.

In many ways, Thanesari's dilemmas and contortions reflect those of his better-known contemporary, Syed Ahmad Khan. Both men operated in a climate of intense anxiety about the divide between colonial India on the one hand, and the world of the Muslim elite on the other. Both men were drawn to the possibilities of the former world, and both were conscious that this exploration could cost them their place in the latter ${ }^{68}$. The solutions that they held up - one in the penal colony, the other in an experimental college - were quite similar. Like Syed Ahmad in Aligarh, Thanesari came to the conclusion that English-language training could be combined with Islamic education, and that the products of this mixing would be culturally and politically viable. Like Syed Ahmad - who, Gail Minault recounts, was outraged by Mumtaz Ali's heresy on the subject of women's rights even as he himself outraged religious conservatives ${ }^{69}$ Thanesari found it necessary to emphasize his religiosity in order to make his 'westernization' palatable to himself and to others.

\section{Family/Man}

Thanesari's conflicted views of Hindus and Muslims, religious Selves and Others, spilled over into his relations with women in the penal colony and free society. There are two generalizations that I would like to extract from the Maulana's family life in the context of his punishment. The first is that for transported convicts, families in the penal colony became vital social, economic, and emotional resources; prisoners sought to acquire them as quickly as possible. At the same time, these convicts often had families on the mainland. In the extraordinary circumstances of penal transportation, each family served its purpose. The 'new' family both supplanted and supplemented the 'old.' Secondly, for male convicts, marriage was not simply a response to loneliness and sexual deprivation. It was also an exercise in social networking between communities within the incarcerated population. This function took on special importance when convict marriages crossed the lines of caste and religion. Intercaste marriage was common in the Andamans; the British - after a prolonged debate adopted a 'don't ask, don't tell' policy on the issue ${ }^{70}$. Thanesari's writing indicates that inter-religious marriages were not unknown. It is evident, also, that such a marriage could be represented as a victory for the husband's community over that of the wife: a significant accomplishment in the context of the political rivalries between semi- 
organized Muslim and Hindu convicts, and between Wahhabis and other Muslims, being narrated by a Wahhabi man.

Convict families served multiple masters. For British administrators who supervised Indian Ocean colonies in which men significantly outnumbered women, and where the colonial power controlled women's entry into local society, the family was a device within which individual criminals and their disorder might be contained ${ }^{71}$. This strategic deployment of the family was not limited to convicts; Carter has noted the phenomenon among indentured workers in Mauritius in the mid-nineteenth century ${ }^{72}$. It is certainly tempting to view the convict family exclusively in terms of power relations and control. Foucault called the family «the privileged locus of emergence for the disciplinary question of the moral and the abnormal ${ }^{73}$ ». This formulation has drawn criticism from even those scholars who have generally been receptive to Foucault. Ignatieff has noted that the Foucauldian view of the family overemphasizes relations of domination and is simplistic to the point of self-parody ${ }^{74}$. It is a mistake to view convict marriage and the convict family in the Andamans solely as systems for the domination of women convicts by male prisoners, and prisoners of both sexes by the incarcerating state. Ignatieff is right to draw attention to «the collaborative and sacrificial elements of family attachment ${ }^{75}$ ", and these elements were undoubtedly present in the families that formed in the society of transported convicts.

When Thanesari was taken to the Andamans, he left his wife and two children behind. Not long after his arrival in Port Blair, he asked that his wife be allowed to join him in the islands. This petition was rejected, he writes, because «the law did not permit that $^{7{ }^{7}}$ ». This statement is puzzling, because the Port Blair authorities had long been eager to import the wives of convicts. It was hoped that wives and families would mitigate a wide array of problems - ranging from violence and political disloyalty to homosexuality - that might be expected in a predominantly male world ${ }^{77}$. The effort to import wives failed because women were generally unwilling to join convict husbands in the Andamans, and not because of reluctance on the part of the British ${ }^{78}$. It seems likely that Thanesari's wife refused to follow her man to the penal colony, and he protected his masculine honor by deflecting the responsibility on to the regime. He writes that his wife was willing «to some extent,» which indicates a lack of enthusiasm on her part ${ }^{79}$.

In 1866, Thanesari married a young Kashmiri Muslim in the Andamans. He writes that she had been brought to the penal colony because of «an unexpected tragedy,» and he emphasizes her youth ${ }^{80}$. This is almost certainly an euphemism for unwed pregnancy followed by infanticide, which was the crime that most often brought women to the Andamans ${ }^{81}$. In a convict settlement where every woman was 'fallen' to some degree, Thanesari was pragmatic about his wife's past, and did not see it as an obstacle in the way of his own social advancement. Nevertheless, he was aware that this marriage might reflect badly upon him in life after the Andamans. This explains the pains he took to underline his second wife's religiosity: after she married him and due to his influence, of course. He writes that she became a devoted follower of the Maulvi Yahya Khan, an elderly Wahhabi convict who befriended Thanesari in the islands ${ }^{82}$. Thanesari's narrative thus represents the marriage as a masculine/Wahhabi triumph over a wayward woman from the Sufi geography of Kashmir.

The Kashmiri woman - we are not told her name - died within a year of her marriage to Thanesari. The Maulana immediately sold her jewelry, and sent the proceeds (some 
three hundred rupees) to his first wife in Panipat. He asked that she use the money to buy shoes and send them to him in Port Blair. Thanesari calculated that he could sell the shoes locally at three or four times the cost of purchase ${ }^{83}$. What is most significant about this exchange is not that individual convict women in the Andamans possessed three hundred rupees worth of jewelry, or that Thanesari was an alert and wellconnected businessman even in the penal colony. These simply indicate the existence of a lively local economy which was both isolated from and connected to the mainland economy. This incomplete isolation generated trading opportunities as well as high prices for everything from gold to shoes, and created the conditions in which enterprising convicts - women as well as men - could acquire and invest wealth. Thanesari's trading venture is more significant because it shows a pragmatic approach to families. Not only did the Maulana immediately and unsentimentally convert his dead wife into capital, he also involved his living wife in his business venture. Wives and families on both sides of the Bay of Bengal functioned as vital points of contact, both social and economic, for convicts in the Andamans. Families served as conduits of money, news and reputations, enabled trade, and allowed transported convicts to maintain (and even expand) their presence in the memory of mainland communities. In other words, families in the penal colony and on the mainland made sure that the Andamans did not become a terrifying black hole in the collective imagination of Indian criminals and their associates, which is precisely what the British had intended the penal colony to be ${ }^{84}$.

After the death of his Kashmiri wife, Thanesari became an eligible bachelor once again. He was young (barely twenty-eight), well-off by convict standards, well-connected and well-employed. He developed a fear that numerous women were trying to «lure» him into marriage, by coming to his house under official pretences. «Women here behave in such a shameless manner that even prostitutes would be ashamed,» he wrote defensively, not unlike other conservative Indian men who have lived overseas among 'disorderly' women ${ }^{85}$. The perception that local women found him irresistible may have been accurate, however, since marriage was one of the few avenues of upward mobility open to convict women in the Andamans ${ }^{86}$. Thanesari fully intended to marry again, and his friends initiated negotiations with two Punjabi Muslim women. Such peer groups of prisoners, which played a leading role in organizing marriages in the Andamans, functioned as surrogate families for individual convicts. There were, apparently, certain misgivings about the women under review: since both were confined to their barracks much of the time, nobody could vouch for their 'character.' The society of convicts did not exist in perfect moral isolation from the society of the free, and concepts like reputation and character played a role in determining women's eligibility as wives. The crimes that brought women to the penal colony could be overlooked in the construction of this character, but local behavior mattered, not least when the groom had to re-enact his wedding and his own moral credentials for a mainland readership. In this particular case, prenuptial negotiations broke down not because of the groom's misgivings, but because both women unexpectedly married other men. "They turned out to be loose women,» Thanesari wrote sadly. «I was looking for a young and virtuous woman ${ }^{87}$ ».

This model of youth and virtue turned out to be a Hindu from Almora in northern India, who was transported to the Andamans in 1868. She had been convicted of trying to murder another woman by pushing her down a well, but Thanesari insisted that his wife was framed by jealous neighbors. While such protestations of innocence are hardly 
surprising, the fact that the Maulana went out of his way to marry a Brahmin is revealing of some of the most critical dynamics of convict society. The revelation begins with the language in which the woman (who, like the Kashmiri, is never named) is described. «She was extremely prejudiced in her Hinduism,» Thanesari writes. «She could not tolerate standing near a Muslim woman or even a touch of her clothes.» Nevertheless, "although she was born in a Brahmin family in a hilly area where there are no Muslims at all, she did not indulge in polytheism or idolatry and never worshipped ${ }^{88}$ ». Thus, even as the future wife is portrayed as being very Hindu, i.e., sufficiently non-Muslim to make conversion meaningful, she retains redeeming qualities that qualify her Other-ness, and create a sympathetic cultural and moral space within which courtship can proceed.

As Thanesari describes it, his wooing of this woman is inseparable from a simultaneous process of religious conquest.

I said: 'If you embrace Islam, it will be good for you in this world as well as on the Day of Judgment, and you will be saved from going to hell.' She was surprised to hear this, but destiny had already decided that she would become a Muslim and give birth to my children. On the very first night after her arrest she saw the beaming face of an old Muslim man in an early morning dream. The man kicked her and said: 'Get up and say Namaz, because it is for your good that you have been arrested.' She woke up frightened, narrated the dream to a Muslim guard, and asked him what it might mean. He said: 'You will certainly become a Muslim as a result of your imprisonment.' Because of destiny and the prophecy in the dream, she accepted my proposal and agreed to embrace Islam and become my wife ${ }^{89}$.

Once the courtship is complete, the wedding comes as the celebration of a successful conquest. It is, however, an accommodating conquest, in which tenderness coexists with communal triumph. Thanesari writes:

On the twenty-seventh night of Ramadan I organized a great feast and converted her to Islam. After she had learned the Muslim rituals and Namaz, I informed the authorities and married her on the fifteenth of April, 1868. Hundreds of people were present at my wedding and the marriage was solemnized by Maulvi Ahmedullah Sahab. On the next day a grand reception was arranged. This wife gave birth to ten of my children, of whom eight are still alive. And this was the wife who accompanied me from Port Blair to India. She spent twenty-two faithful and devoted years with me. She is a pious and adaptable woman ${ }^{90}$.

We do not know why the woman in question agreed to marry Thanesari. It is best to reject romantic passion as a motive, since nothing in the Maulana's writing indicates that either was besotted. It is likely that Thanesari exaggerated her initial Hindu rigidity; he was probably more accurate when he referred to her as adaptable. For her, marriage and religious conversion opened doors that would otherwise have remained closed. Her status in her original society on the mainland - especially her marital prospects - had already been disrupted by criminal conviction, arrest, and penal transportation ${ }^{91}$. This made converting to Islam and marrying a Muslim relatively painless. On the contrary, these gave her access to the social and economic resources of a privileged husband.

Thus, 'inter-religious' marriage in the Andamans could serve multiple purposes: it boosted Thanesari's status among Muslim convicts, and repaired his wife's damaged social status by allowing her to reinvent herself. For both husband and wife, children provided additional status in local society; Thanesari recounts the feasts, attended by large numbers of elite convicts, that surrounded the birth of sons and daughters. Also, 
for the Maulana, his new family in the penal colony provided a way of remembering the family he had left behind on the mainland. In one of the more poignant instances in the history of displacement and migration, Thanesari named his new children after his old. When he was told that his oldest son, Mohammad Sadiq, had died in Panipat, he writes, «I consoled myself with the fact that I had with me his namesake. I informed my wife in India about the replacement of the dead son with a namesake ${ }^{92}$ ».

It seems clear that the two families - the old and the new - became partially integrated as the time of Thanesari's release approached. His financial contacts with his first wife continued; in 1882, he sent her money, jewelry and clothes to meet the expenses of his oldest daughter's wedding. He could not play the dominant role in arranging the marriage - that responsibility passed to the bride's mother - but he tried, nevertheless, to preserve some authority as a man and a Muslim, telling his readers that he had instructed his wife to "marry our daughter to some religious-minded boy ${ }^{93}$ ». $\mathrm{He}$ continued to hope that he would be released in time to be present at the wedding, and he bought presents and souvenirs in anticipation.

Thanesari did not, however, lose sight of his local family. After his release was announced in January of 1883 , he stayed on in the Andamans until November. He was waiting for his wife's release, and for the birth of another child: his wife in the Andamans was pregnant at this time. Convicts in the penal colony sometimes went back to the mainland leaving their local spouses and children behind in the Andamans ${ }^{94}$; Thanesari was not one of them. He used the extra time in the penal colony to negotiate with the colonial authorities over an acceptable job on the mainland, and to sell his possessions at the best possible prices. He campaigned, also, to have his home converted into a mosque. This last project was almost certainly intended for mainland consumers of his martyred Self: he writes that it made him more popular than ever among Muslim convicts, and that the plan fell through because the Port Blair regime feared that the mosque would become a center of Wahhabi political activity ${ }^{95}$.

In the autumn of 1883, Thanesari left the penal colony on board the SS Maharani, accompanied by his wife, eight children, and eight thousand rupees worth of valuables. When he reached the mainland, he moved quickly to determine the relationship between his two families. He was clear that he wanted to retain his ties to his original family, which had survived twenty years of physical separation and intermittent communication. He visited his old wife in Panipat, and wondered at the sheer familiarity of this rediscovered world: «I felt as though I had left my family this morning, and returned later in the day ${ }^{96} \%$.

Nevertheless, he understood that things had, in fact, changed: he notes, with a sense of shock, that the son who was less that a year old at the time of the Maulana's arrest was now an intimate stranger of twenty. We are not told how his first wife's social relationships had evolved over the two decades of her husband's absence, yet they must have changed. Under the circumstances, Thanesari was clear that his primary family was the one he had acquired in the penal colony. After five days in Panipat, he returned to Ambala. He distributed his accumulated wealth between his two wives, and adopted a somewhat disingenuous posture as a renouncer of material comforts («now my personal property consists of only a few books and some clothes») ${ }^{97}$. 


\section{Conclusion}

Jafar Thanesari's account of his years in the Andamans indicates how convicts who possessed certain cultural and professional assets were able utilize the experience of penal transportation to reinvent themselves, or at least to adjust their identities, not only in the penal colony but also in the 'free' society of the mainland. For all its unreliability, the narrative confirms that some prisoners were able to negotiate a mutually beneficial arrangement with the British authorities in the Andamans. For literate convicts, the experience of penal transportation generated opportunities for positive social mobility that probably surpassed opportunities that existed in free society.

Thanesari's narrative also adds to our understanding of the political community and the family in a nineteenth-century Indian penal colony, complicated as these were by the circumstances of dislocation, distance and a intensely cosmopolitan prison. In spite of the mixing of ethnicities and religions, communal identities remained intact, and in some contexts, became more sharply defined. But in other contexts, the boundaries of community could be suspended, or re-imagined to delineate an Indian convict identity determined by the interrelated forces of colonialism and punishment. The exploration of new languages and ideas was profitable and irresistible, but it also generated intense anxieties about the perforation of cultural boundaries. This made religious selfassertion that much more important. Marriage, families and the convict experience itself could be utilized rhetorically to raise the status of the 'conqueror' in the eyes of his community.

\section{BIBLIOGRAPHY}

\section{Primary sources:}

Records of the Home Department (Judicial, Public and Port Blair Branches), Government of India (GOI), 1858-1900; National Archives of India (NAI), New Delhi.

Administration report of the Hazaribagh Reformatory School, 1883, NAI.

\section{Secondary sources:}

Anderson, B., Imagined communities, New York, Verso, 1983.

Anderson, C., Convicts in the Indian Ocean, London, Macmillan, 2000.

Arnold, D., Hardiman, D., Eds, Selected Subaltern Studies VIII, Delhi, Oxford University Press, 1994.

Ballyn, S., Bradley, J., Duffield, I. et al., in Frost, L., Maxwell-Stewart, H., Eds, Chain letters: narrating convict lives, Melbourne, Melbourne University Press, 2001. 
Carter, M., Lakshmi's legacy: the testimonies of Indian women in $19^{\text {th }}$ century Mauritius, Mauritius, Éditions de l'Océan Indien, 1994.

Carter, M., Servants, sirdars and settlers: Indians in Mauritius, 1834-1874, Oxford, Oxford University Press, 1995.

Carpenter, M., Six months in India, London, Longman \& Green, 1868.

Freitag, S., Collective Crime and Authority in North India, in Yang, A. (ed.), Crime and Criminality in British India, Tucson, University of Arizona Press, 1985, pp. 140-163.

Freitag, S., «Contesting in Public: Colonial Legacies and Contemporary Communalism,» in Ludden, D., Ed., Contesting the nation: religion, community, and the politics of democracy in India, Philadelphia, University of Pennsylvania Press, 1996, pp. 211-234.

Foucault, M., Discipline and Punish, New York, Vintage, 1978.

Gordon, S., The Marathas, 1600-1818, Cambridge, Cambridge University Press, 1993.

Grewal, J.S., The Sikhs of the Punjab, Cambridge, Cambridge University Press, 1990.

Hasan, M., «The Myth of Unity,» in Ludden, D., Ed., Contesting the nation: religion, community, and the politics of democracy in India, Philadelphia, University of Pennsylvania Press, 1996, pp. 185-210.

Hay, D., Linebaugh, P., Thompson, E.P., Albion's fatal tree: crime and society in $18^{\text {th }}$-century England, New York, Pantheon, 1975.

Hunter, W.W., Rulers of India - The Earl of Mayo, Oxford, Clarendon Press, 1892.

Ignatieff, M., «State, Civil Society and Total Institutions,» in Cohen, S., Scull, A., Eds, Social control and the state, New York, St. Martin's Press, 1983, pp. 75-101.

Jalal, A., Partisans of Allah: Jihad in Theory and History, paper presented at the South Asia Speaker Series, Washington University, October 3, 2003.

Lelyveld, D., Aligarh's First Generation: Muslim Solidarity in British India, Princeton, Princeton University Press, 1978.

McLane, J., Indian nationalism and the early Congress, Princeton, Princeton University Press, 1977.

Metcalf, B. Daly, Islamic revival in British India: Deoband, 1860-1900, Princeton, Princeton University Press, 1982.

Minault, G., The Khilafat movement: religious symbolism and political mobilization in India, New York, Columbia University Press, 1982.

Minault, G., Women'sRights in Islam and Women's Journalism in Urdu, in Jones, K., Ed., Religious controversy in British India, New York, SUNY Press, 1992, pp. 179-199.

Oberoi, H., Sikh Fundamentalism, in Kaviraj, S., Ed., Politics in India, Delhi, Oxford University Press, 1999, pp. 318-328.

Pybus, C., Hamish-Stewart, M., American citizens, British slaves: Yankee political prisoners in an Australian penal colony, East Lansing, Michigan State University Press, 2002.

Redfield, P., Space in the tropics: from convicts to rockets in French Guiana, Berkeley, University of California Press, 2000.

Robinson, F., The 'Ulama of Farangi Mahall and Islamic Culture, Delhi, Permanent Black, 2001.

Savarkar, V.D., My transportation for life, Bombay, Veer Savarkar Prakashan, 1984.

Semple, J., Bentham's prison, Oxford, Clarendon Press, 1993. 
Sen, S., Disciplining Punishment: Colonialism and Convict Society in the Andaman Islands, Delhi, Oxford University Press, 2000.

Sen, S., «Rationing Sex: Female Convicts in the Andamans,» South Asia, 1999, 30,1, pp. 26-59.

Singh, U. K., Political Prisoners in India, Delhi, Oxford University Press, 1998.

Thanesari, M. J., Kalapani, Delhi, Urdu Markaz, 1964.

Wiener, M., Reconstructing the criminal: culture, law and policy in England, 1830-1914, Cambridge, Cambridge University Press, 1990.

Yang, A., Ed., Crime and criminality in British India, Tucson, University of Arizona Press, 1985.

Yang, A., Slave/Convict/Laborer, Indian/Malay/Chinese, paper presented at the annual meeting of the Association of Asian Studies, San Diego, 2000.

\section{NOTES}

2. Freitag (1985, pp. 108-127, 140-163).

3. Sen (2000, pp. 1-30).

4. Ballyn, Bradley, Duffield, et al. (2001); Pybus, Maxwell (2002); Redfield (2000).

5. Anderson C. (2000); Yang (2000).

6. Thanesari (1964, pp. 4-54). The published work is in Urdu; the page numbers cited here are from an unpublished English translation in my possession.

7. A distinction must be made, here, between Mutiny-era political prisoners like Thanesari, and those who were imprisoned explicitly in connection with nationalist agitation in the $20^{\text {th }}$ century. The latter, Ujjwal Singh has noted, were ideologically distinct from the «common» convicts, and not intended for any kind of rehabilitation (Singh, 1998, pp. 23-69). The earlier generation of rebels, however, were seen by the British as relatively amenable to reincorporation into the political order of the colonial state, provided they could be attached to the 'right' leadership (Sen 2000, pp. 61-75).

8. The term 'convict elite' may sound like an oxymoron, but prisoners who had been in the islands for some years, those who possessed special talents, and those who demonstrated particular political loyalty, were all rewarded with various degrees of freedom, power, money, and sexual opportunity (Sen, 2000, pp. 100-119).

9. Hasan (1996, pp. 185-208).

10. Oberoi (1999, p. 328).

11. The Wahhabi movement sought to rescue Islam from a moral and political corruption that was implicitly linked to colonialism. Metcalf (1982, pp. 299-309).

12. Jalal (2003).

13. Ibid.

14. Rudolph et al. (2000, pp. 27-38).

15. Robinson (2001, pp. 177-210).

16. Minault (1982); Lelyveld (1978).

17. Sen (1999).

18. Wiener (1990, p. 47).

19. Semple (1993, pp. 161-165).

20. GOI Home, Judic., 30 Dec. 1871, no. 94-98, pp. 2967-3009.

21. Arnold (1994, pp. 148-187).

22. GOI Home, Judic., 9 Jan 1869, no. 55-72, 75-435.

23. GOI Home, F.J. Mouat to Rivers Thompson, 6 Jan. 1860. 
24. GOI Home, Port Blair, Oct. 1873, no. 60-62.

25. Sen (2000, pp. 86-92).

26. GOI Home, Judic., Apr. 1872, no. 81-82.

27. GOI Home, Judic., 7 Oct. 1871, no. 30-32.

28. Thanesari (1964, p. 57).

29. Ibid.

30. Ibid, pp. 13-15.

31. Sen (2000, pp. 175-182).

32. Thanesari (1964, p. 78).

33. Ibid.

34. Even in 1871, administrators in Port Blair muttered darkly about what they might do if «a time of danger like 1857 should again visit India.» GOI Home, Public Branch, 7 Jan. 1871, no. 128-135; 22 Apr. 1871, no. 53-54.

35. GOI Home, Judic., 24 Sept. 1870, no. 6-6.

36. Sen $(2000$, p. 96$)$.

37. Hay, Linebaugh, Thompson (1975, pp. 39-41).

38. Thanesari (1964, pp. 79, 83).

39. Ibid., p. 105.

40. Ibid., pp. 116-117. Colonial jailors frequently complained that over-zealous police surveillance ruined the rehabilitation of released prisoners. See Administration Report of the Hazaribagh Reformatory School, 1883, NAI.

41. Ibid., pp. 83, 90 .

42. Ibid., p. 90.

43. Anderson (2000, pp. 91-94).

44. GOI Home, Judic., 15 July 1871 , no. 47A.

45. Sen (2000, pp. 105-106, 221-223).

46. Savarkar (1984, pp. 125, 198). Savarkar is widely regarded as the pre-eminent ideologue of Hindu nationalism in $20^{\text {th }}$-century Indian politics. He was imprisoned in the Andamans between 1911-1921.

47. Thanesari (1964, p. 83).

48. McLane (1977, pp. 271-331).

49. Freitag (1996, pp. 211-223).

50. Thanesari (1964, pp. 79-80).

51. Ibid., p. 81.

52. It is entirely possible that the previous charge of embezzlement also had some basis in truth. Thanesari is less than energetic in denying it.

53. Thanesar (1964, p. 82)

54. Ibid., pp. 17, 86-87.

55. Ibid., p. 68.

56. Hunter (1892, pp. 192-195); Thanesari (1964, pp. 86-89). Thanesari himself developed his ideas about colonial politics by reading Hunter's histories, and by reacting angrily at what he saw as Hunter's prejudice against the Wahhabis.

57. Thanesari (1964, pp. 68-69).

58. Ibid., p. 97.

59. Grewal (1990); Gordon (1993).

60. Cases in point are Abdul Bari and Maulana Azad, who found themselves drawn into Indian nationalist politics in the aftermath of World War I, albeit with different priorities, levels of enthusiasm, and interpretations of the political problem at hand. Minault (1982, pp. 25-43).

61. Anderson (1983, pp. 12-19).

62. Sen (2000, pp. 100-109). 
63. Thanesari (1964, pp. 109-110).

64. Ibid., p. 81.

65. Ibid., p. 91.

66. Ibid.

67. Ibid., p. 92.

68. Lelyveld (1978, pp. 102-146).

69. Minault (1992, p. 182).

70. GOI Home, Port Blair, Oct. 1884, no. 81-82.

71. Sen (1999).

72. Carter (1995, p. 237; 1994, pp. 113-146).

73. Foucault (1978, p. 215).

74. Ignatieff (1983, p. 98).

75. Ibid.

76. Thanesari (1964, p. 70).

77. Sen (1999).

78. For convicts' families to join them in the Andamans, clearance was required from the Port Blair authorities as well as from the provincial administration on the mainland. Usually, the mainland authorities did not object to this, provided there was no significant financial cost. Sometimes cost was not a deterrent: Thanesari notes that the Government of Bengal arranged for the family of Mian Abdul Ghaffar, a convict who had been transported in connection with the Rebellion of 1857, to travel to the Andamans at government expense. Thanesari (1964, p. 96).

79. Ibid., p. 75.

80. Ibid/.p. 70.

81. GOI Home, Port Blair, June 1890, no. 74-78.

82. Thanesari (1964, p. 74).

83. Ibid., op. cit.

84. GOI Home, Judic., 19 June 1869, no. 14-15 A.

85. Thanesari (1964, pp. 75, 110).

86. Sen (1999).

87. Thanesari (1964, p. 75).

88. Ibid., p. 76.

89. Ibid., p. 77.

90. Ibid.

91. It was not uncommon for women sentenced to long terms of imprisonment in mainland Indian jails to petition the authorities to be transported to the Andamans, where they might find husbands, a measure of freedom, and economic opportunities. Mary Carpenter, touring Indian prisons in the 1860s, encountered several such petitioners in Calcutta's Alipore Jail. Carpenter (1868, pp. 202-203).

92. Thanesari (1964, p. 98).

93. Ibid., 103.

94. GOI Home, Port Blair, Apr. 1877, no. 5-6, 71-72.

95. Thanesari (1964, pp. 105-106).

96. Ibid., p. 117.

97. Ibid., p. 113. 


\section{ABSTRACTS}

This article analyzes some of the key social and political dynamics of the British-Indian penal colony in the Andaman Islands, from the perspective of the individual convict. It focuses on a rare Indian convict autobiography from the nineteenth century: the Urdu memoirs of the Maulana Muhammad Jafar Thanesari, a Wahhabi Muslim activist who was arrested in 1863 for conspiring to smuggle funds to anti-British mujahideen in Afghanistan. Beginning in 1866, Thanesari spent nearly eighteen years in the penal colony, and then returned to the mainland with a new wife, new children, and considerable wealth and social status. The colonial regime's punishment of Thanesari was quite successful, because it resulted in the conversion of a troublemaker into a moderately satisfied and law-abiding subject of the crown. It did not, however, eradicate all inclinations and opportunities for dissent - rather, it gave new form to dissident gestures. The article focuses first on the issue of convict labor. Next, the article examines Thanesari's perceptions of the politics of religion and race in the Andamans. The final area of analysis concerns Thanesari's acquisition of a family in the Island.

Cet article analyse certaines des principales dynamiques sociales et politiques de la colonie pénale anglo-indienne des îles Andaman, du point de vue de l'individu détenu. Il se concentre sur l'une des rares autobiographies d'un détenu indien au XIX ${ }^{\mathrm{e}}$ siècle, les mémoires, rédigées en urdu, du Maulana Muhammad Jafar Thanesari, un militant musulman wahabite qui fut arrêté en 1863 pour avoir comploté un transfert de fonds à des mujahidines anti-britanniques en Afghanistan. À partir de 1866, Thanesari vécut près de 18 ans dans la colonie pénale, avant de revenir sur le continent avec une nouvelle épouse, de nouveaux enfants, une grande fortune et un statut social prestigieux. La punition infligée par le régime colonial à Thanesari fut efficace, puisqu'elle eut pour effet de transformer un trublion en un sujet de la Couronne plutôt satisfait et respectueux de la loi. Elle ne parvint cependant pas à éliminer toutes ses inclinations et ses occasions de dissidence, mais donna de nouvelles formes à leurs manifestations. L'article s'arrête d'abord sur la question du travail forcé. Puis il examine la perception qu'avait Thanesari de la politique religieuse et raciale dans les Andaman. Enfin, il analyse la constitution d'une famille locale par Thanesari.

\section{AUTHOR}

\section{SATADRU SEN}

Assistant Professor, History Department, Washington University, Campus BOX1062, One

Brookings Drive, St. Louis, M063130, ssen@artsci.wustl.edu

Satadru Sen is assistant professor of South Asian history at Washington University in St. Louis. He is the author of Disciplining Punishment: Colonialism and Convict Society in the Andaman Islands (Oxford University Press, 2000), and Migrant Races: Empire, Identity and K.S. Ranjitsinhji (Manchester University Press, forthcoming 2004). He is also the co-editor of Confronting the Body: The Politics of Physicality in Colonial and Post-Colonial South Asia (Anthem Press, 2004). He is currently working on a study of childhood and colonialism in India. 